\title{
Comparison of the properties of scutched flax and flax tow for composite material reinforcement
}

\author{
Martin Nicolas ${ }^{1,3,{ }^{*}}$, Davies Peter ${ }^{2}$, Baley Christophe ${ }^{1}$ \\ ${ }^{1}$ Univ Bretagne Sud, EA 4250, LIMATB, F-56100 Lorient, France. \\ 2 IFREMER, Ctr Bretagne, F-29280 Plouzane, France. \\ ${ }^{3}$ Van Robaeys Freres, F-59122 Killem, France.
}

Corresponding author : Nicolas Martin, email address : nicolas.martin@univ-ubs.fr ; peter.davies@ifremer.fr ; christophe.baley@univ-ubs.fr

\begin{abstract}
:
The industrial production of flax fibers yields two fibrous products: scutched fibers are valuable for their length, fineness and cleanness, while tows are entangled, impure and are low-priced. There is a need for technical data to compare these two kinds of fibers beyond the difference of appearance, and to assess their potential as composite material reinforcements. In this work, we have compared the properties of scutched flax and flax tows from the same batch. The morphology was first assessed by measuring the length, cleanness and fineness of fiber bundles. The tensile properties of single fibers and of unidirectionally reinforced epoxy composites were then measured. The results show that the morphology of flax tows is different from but close to the morphology of scutched flax. Tow bundles were $15 \%$ shorter than scutched flax bundles and tow bundles were $25 \%$ thicker than scutched flax bundles. The tensile properties of single fibers were in the same range. Tensile properties of the unidirectional composites show a similar evolution of properties versus fiber volume fraction. The use of scutched flax allowed volume fractions of 0.7 to be achieved while tow volume fraction was limited to 0.6. Despite the visual and morphological difference between tows and scutched flax both can be good candidates for composite reinforcement in high performance applications.
\end{abstract}

\section{Highlights}

- The properties of scutched flax and flax tows were studied. Structure and morphology of the materials were analyzed. Tensile properties of single fibers were not significantly different. Tensile properties of unidirectional composites were not different.

Keywords : Flax fibers, Scutching, Flax by-products, Composite materials 


\section{Introduction}

For more than 60 years, the composites industry has been dominated by fiberglass reinforcements. Although these materials have good performance, ease of processing and low price, issues arise from their environmental impact i.e. resource, energy consumption and disposal. These problems and the growing interest in sustainability have led to a significant increase in the number of studies on plant fiber reinforced composite materials in the two last decades.

Plant fibers are renewable, biodegradable and have a low density. The use of plant fibers to replace E glass fibers in composite materials can reduce the environmental impact of parts (Joshi et al., 2004; Le Duigou et al., 2011). Plant fibers can be used with thermoplastic matrix polymers to enable recycling while preserving original properties (Bourmaud and Baley, 2009; Le Duigou et al., 2008). Composites made of a combination of biodegradable matrix and plant fibers can be composted, which offers another option for end-of-life management.

A wide range of plant fibers have been studied for composite reinforcement including hemp, jute, sisal and flax (Franck, 2005). Among them, flax fibers have excellent specific mechanical properties and are being evaluated as a replacement for E-glass fibers (Baley, 2002).

Flax (Linum usitatissimum) is a local resource in northern Europe, it is an annual summer crop. The structure of the plant is complex (Akin et al., 1996; Franck, 2005; Morvan et al., 2003). The height of the plant can measure up to $1 \mathrm{~m}$ and the stem width is about $2 \mathrm{~mm}$. Flax plants contain bast fibers along their length at the periphery of the stem, in bundles embedded in the cortical parenchyma. These long strands contain a large number of individual fibers i.e. originating from a single cell (10-80mm long, $10-20 \mu \mathrm{m}$ wide). These are 
joined together by their ends and sides to form a bundle. The cross section of a bundle can contain 30-40 individual fibers. In the bundle, the fibers are bonded together by middle lamellae containing mainly pectic cements. In the middle of the stem, is located the xylem, a woody core.

The term fiber has to be clarified. In this paper we will use the term single fiber to refer to the single cell, and fibers or fiber bundle when referring to single fibers grouped together.

The production of flax includes two parts; cultivation of the plant and extraction of the fibers. In Europe, the cultivation begins with sowing at the beginning of spring, then flowering occurs in June, followed by seed ripening in July. Stems are subsequently pulled from the ground and laid on the field for dew retting. Retting is carried out to ease the further decortication process. Moisture and warm weather allow fungi and bacteria to colonize the stems (Brown and Sharma, 1984; Henriksson et al., 1997). These fungi release several enzymes that degrade pectins (Meijer et al., 1995; Rosemberg and De França, 1967). As a result the epidermis, cortical parenchyma, and middle lamellae are degraded and fiber bundles split (Akin et al., 1996), facilitating the removal of shives and cortical tissues (Pallesen, 1996).

To be used in textile or composite applications, fibers have to be extracted from the stem. Industrial production of flax fibers from flax plants is performed by a decortication process also called scutching. The aim of this step is to extract the fibers from the stem by removing the woody core (Akin et al., 2005; Salmon-Minotte, 2005; Sultana, 1992). This process yields scutched fibers which is the main product and a series of by-products mainly flax shives, tows and seeds. Scutched fibers are made of aligned long flax fibers containing a small amount of shives, depending on the efficiency of the scutching process and the degree of retting. Shives are formed by the fragmentation of the woody core. During scutching, some 
parts of the plants are withdrawn from the material flow and falls into a secondary circuit. These fibrous parts are called tows. They are made of misaligned and entangled flax fibers, and contain a large quantity of shives.

Scutched fibers have the highest value of all flax products. Scutched flax can be directly hackled to be used for yarn spinning. Tows have less value as they must undergo further opening and carding operations to be cleaned of shives and aligned prior to spinning. Tows are considered today to be undesirable and unavoidable by-products. These fibers are sold at about half the price of scutched flax. For composite material reinforcement, the optimal presentation of flax fibers is not defined but as a general rule unidirectional or weaved preforms are produced with hackled flax in the form of highly twisted linen yarn or low twist hackled strands. Tows are mainly used in lower performance and lower price materials, e.g. needle punched non-woven. A few previous studies have compared the mechanical properties of scutched flax and tow. Andersons et al., (2009) compared the tensile properties and number of defects of unitary flax fibers originating from tows and scutched flax. The tests were performed on $5 \mathrm{~mm}$ gauge length tensile specimens. Their study showed that the strength of tow single fibers $(860 \pm 330 \mathrm{MPa})$ was higher than the strength of scutched flax single fibers $(660 \pm 330 \mathrm{MPa})$. The defects spacing i.e. length between two defects on a fiber, was the same for both. Van de Weyenberg et al., (2003) studied the mechanical properties of epoxy/flax UD composites reinforced with different products and processing. This study showed that materials made of carded tows had better strength at break than scutched flax, but had a lower stiffness caused by the much shorter fiber lengths in these bundles.

The inclusion of flax tows in high performance material reinforcement could be economically interesting. More data on morphology, length, impurity and mechanical properties are needed in order to evaluate the potential of tow fibers for composite reinforcement. 
In this study, we have compared the properties of scutched flax and tow. Optical and scanning electron microscopy was used to study the surface and morphology of the single fibers and bundles. Image analysis was employed to examine the size of the fiber bundles and the quantity of single fibers. The quantity of impurities was assessed by measuring the amount of shives and chemical extraction of the fibers. Tensile properties of single fibers were measured. Unidirectional composite material tensile specimens were manufactured by wet impregnation of aligned fiber bundles with epoxy resin and a subsequent individual molding. The tensile properties of these specimens were then measured.

\section{Materials and methods}

\subsection{Raw fibers}

The flax plants studied here are of the Alizée variety, coming from an industrial production, grown in France in the coastal region of Picardy in 2012. Flax stems were sown on $23^{\text {rd }}$ March with a seed rate of $1900 . \mathrm{m}^{-2}$, around $90 \%$ of the seeds were germinated. Stems were pulled on $17^{\text {th }}$ July, before being laid in the field to allow retting. Flax stems were collected on $8^{\text {th }}$ August and then stored in a dry building. Hence, the retting lasted 23 days. The surface of the field was 10 hectares. The stem yield after collection was $7 \mathrm{~kg} \cdot \mathrm{m}^{2}$. After harvesting, the flax stems were scutched by Van Robaeys Frères ${ }^{\circledR}$ (Killem, France).

Figure 1 is a diagram of the scutching line used in this work. At the entrance to the scutching line the bales of retted stems are unrolled and an even layer of flax stems is manually entered into the line. The flax stems are oriented perpendicular to the direction of the line. Throughout the whole machine, the orientation of the flax stems remains perpendicular to the material flow direction. The first processing step is the removal of the seeds. Then a dividing unit reduces the layer thickness by increasing the speed of the material 
flow. The flax stems leaving the divider are taken between two belts and fed to the breaker rolls.

During the second step the materials are passed through the breaking units. The stems are passed between a series of fluted rollers to break the woody cores. The core particles (the shives) fall into a hopper underneath the breaking units where they are aspirated. Most of the shives are removed in the breaking units but a certain amount remains stuck on the bundles surface. At this point, the materials consist of crushed stems and fiber bundles containing shives. During the third step, the materials are fed into the beating units. The materials are passed through two counter-rotating cylinders fitted with blades. These blades scrap the stems to remove the remaining broken shives. This is where tows can be created. The tows fall into a secondary circuit under the scutching cylinders and are collected together with shives. There are two beating units, one for the bottom part of the plant, and another one for the upper part. At the end of the scutching line, the scutched flax is rolled into bales.

In this study, the scutching process yielded $25 \%$ of scutched fibers, $11 \%$ of tows, $5 \%$ of seed and $59 \%$ of shives and soil residues. The scutching rate, which is the weight of stem processed within an hour, was $1863 \mathrm{~kg} \cdot \mathrm{h}^{-1}$. The speed of the scutching cylinders was $200 \mathrm{rpm}$. For this study, tows were collected from the two beating units and were not further processed.

\subsection{Study of the fibers morphology and composition}

After the scutching process the length of the fiber bundles was measured on 100 specimens for tows and scutched fibers. Purity of the two materials was assessed by shaking and manually removing the shives stuck on the fiber bundles surface with tweezers. The samples were weighed before and after cleaning.

After shive cleaning, an extraction of the fibers was performed to quantify the amount of remaining material at the bundle surface by measuring the weight loss after extraction. 
These extractions were carried out according to methods described in the literature (Goubet et al., 1995; Jauneau et al., 1992). Samples were first washed with distilled water at room temperature to remove dust (step A), before being washed 3 times with boiling distilled water for $1 \mathrm{~h}$ (step B). Subsequently, samples were washed with a $\mathrm{Na}_{2}$-ethylene-diamine-tetraacetic acid (EDTA) solution $(0.25 \%)$ for $1 \mathrm{~h}$ then rinsed twice in boiling distilled water for 1 hour (step C). Between each step, the fibers were dried for $12 \mathrm{~h}$ at $80^{\circ} \mathrm{C}$ and weighed.

Cross sectional morphology of the flax bundles was assessed to quantify the fineness of the bundles. A few fiber bundles were embedded in an epoxy resin and their cross section was polished. Then a series of SEM images of the sample surface was taken at x200 magnification. Image analysis was performed using ImageJ (Schneider et al., 2012). An appropriate black and white threshold was chosen on the image to separate the flax bundles (black) from the matrix (white) (Figure 2). Finally the cross sectional area of the bundles was automatically measured by the software.

In addition, the average cross sectional diameter of elementary fiber was manually measured for the two products by optical microscopy. The cross sectional diameters of 250 single fibers were measured. As flax fibers exhibit a polygonal section, the longest and smallest distances were recorded and values were averaged. This value is named cross sectional diameter or $\phi_{\text {cross }}$ in the text.

\subsection{Tensile test on single fibers}

Single flax fibers were hand extracted from fiber bundles. Single fibers originating from scutched fibers and tows were selected in the central zone of the stem to limit the scatter in mechanical properties. Charlet et al. (2007) have shown that the tensile properties of single flax fibers are different from stem root to stem tip, and exhibit a maximum value in the central area of the stem. Single fibers were then bonded onto a paper frame before being clamped in an MTS Synergie RT/1000 tensile machine equipped with a 2N load cell. Tensile tests were 
carried out according to the AFNOR XP T-501-2 standard at controlled temperature $\left(23{ }^{\circ} \mathrm{C}\right)$ and humidity (50\%). Samples were kept at least 48 hours under these conditions prior to the test. Single flax fibers exhibit a nonlinear tensile behavior (Baley, 2002), so the apparent tensile modulus was measured by calculating the slope of the curve in the last linear part (Figure 8a). The test gauge length was $10 \mathrm{~mm}$ and crosshead displacement speed was 1 $\mathrm{mm} \cdot \mathrm{min}^{-1}$. Calculated values of tensile modulus and failure strain take into account a correction for the compliance of the test machine. Single fiber apparent diameter was measured at three points along the fiber. The mean value was used to calculate the fiber cross section area considered for tensile properties. Around 60 fibers were tested for each condition. The results were analyzed statistically using the Student's t test.

\subsection{Composites manufacturing}

Scutched flax was processed as received whereas flax tows were manually untangled and aligned to allow the material to be processed into unidirectional composites. The flax bundles did not have any twist. Tow bundles were hand shaken to remove shives. Fiber bundle samples cut to a length of $10 \mathrm{~cm}$ were used. Samples were selected in the central zone of the stem. Composite materials were manufactured following the procedure described by (Coroller et al., 2013). An epoxy resin and its amine hardener (Epolam 2020, Axson technologies) were used as a matrix. Resin and hardener were mixed at a 100/34 mass ratio before composite processing. Figure 3 shows a diagram of the molding device. Fiber bundle strands of $10 \mathrm{~cm}$ length were wet impregnated with epoxy resin and inserted into an aluminum rail. A second rail was placed on top of the mixture and pressure was applied to obtain the desired thickness. The pressure was maintained during hardening. After room temperature cure $\left(23^{\circ} \mathrm{C}-24 \mathrm{~h}\right)$, samples were post cured following the supplier's recommendation $\left(40^{\circ} \mathrm{C}, 3 \mathrm{~h} ; 60^{\circ} \mathrm{C}, 2 \mathrm{~h} ; 80^{\circ} \mathrm{C}, 2 \mathrm{~h} ; 100^{\circ} \mathrm{C}, 4 \mathrm{~h}\right)$. Glass/epoxy tabs $\left( \pm 45^{\circ}\right)$ were 
bonded on tensile specimen ends with an Araldite 2011 (Huntsman) adhesive and cured $\left(23^{\circ} \mathrm{C}, 24 \mathrm{~h} ; 50^{\circ} \mathrm{C}, 12 \mathrm{~h}\right)$ before composite testing.

\subsection{Density and fiber fraction measurements}

Fiber volume fraction of the composites was assessed after curing. First of all, the apparent volume fraction and apparent void content were estimated by analyzing cross sectional SEM images of 4 tensile specimens of composites materials with ImageJ. Figure 4 shows a cross section transverse to fibers of a unidirectional composite. Appropriate black \& white thresholds were used to differentiate the components. The apparent void content was measured to be less than $1 \%$ and was neglected in fiber volume fraction measurement. Then the fiber volume fraction $\left(V_{f}\right)$ was assessed by carrying out density measurement of the four aforementioned tensile samples. Density measurements were performed according to ISO 1183-1 using the immersion method with $1 \mathrm{~g}$ samples and pure ethanol as a fluid. The density is given by Equation 1 .

$$
\rho_{c}=\frac{m_{\text {air }}}{m_{\text {air }}-m_{\text {eth }}}\left(\rho_{e t h}-\rho_{\text {air }}\right)+\rho_{\text {air }}
$$

where $\rho_{c}, m_{\text {air }}, m_{e t h}, \rho_{e t h}$ and $\rho_{\text {air }}$ are respectively the density of the composite material, the sample weight in air, the sample weight in ethanol, the density of ethanol and air at experiment temperature. Density of scutched and tow fibers were measured to be $1.398 \mathrm{~g} . \mathrm{cm}^{-3}$ and 1.374 g.cm ${ }^{-3}$. Matrix density was measured to be $1.161 \mathrm{~g} . \mathrm{cm}^{-3}$. Fiber volume fraction was then estimated using an expression derived from the rule of mixtures of composite density (Equation 2).

$$
V_{f}=\frac{\rho_{c}-\rho_{m}}{\rho_{f}-\rho_{m}}
$$

where $V_{f}, \rho_{c}, \rho_{m}$ and $\rho_{f}$ are respectively the fiber volume fraction, density of the composite material, matrix density and flax fiber density. 
Finally, values of volume fraction measured by the image analysis method and the density method were compared for the 4 samples. Values were very similar for the 2 methods; hence it was decided to measure the volume fraction of the whole series of tensile specimens by the density method.

\subsection{Tensile test of composites}

Tensile tests were performed on the tensile specimens described in section 2.4. An Instron 5566 tensile machine was used. The capacity of the load cell was $10 \mathrm{kN}$ and a $25 \mathrm{~mm}$ nominal length extensometer was used. The crosshead displacement speed was $1 \mathrm{~mm} \cdot \mathrm{min}^{-1}$. The tensile modulus was obtained by calculating the slope of the tensile curve between $\varepsilon=0.01$ and $\varepsilon=0.011$.

\subsection{Scanning electron microscopy}

The samples were sputter coated with a thin gold layer using an Edwards Scancoat Six apparatus, before being examined with a Jeol JSM 6460LV scanning electron microscope. For raw fiber observations, the samples were bonded onto a carbon tape allowing observation of their length. Before coating of the unidirectional composite materials, samples were embedded in an epoxy matrix and polished. 


\section{Results and discussion}

\subsection{Morphological study of the two products}

The length of the two materials was first examined. Figure 5 is a photograph of scutched flax (A), flax tows (B) and untangled tows (C). Scutched fibers consist of rather aligned strands with almost no shives, while tows fibers are entangled and contain shives as the two by products were mixed during scutching.

The lengths of 100 bundles of scutched flax and flax tows were measured with a ruler. Tow bundles were manually untangled before measurement. Tows bundles measured $64 \pm 19 \mathrm{~cm}$ with a maximum of $85 \mathrm{~cm}$ and a minimum of $12 \mathrm{~cm}$ and scutched bundles measured $74 \pm 9$ $\mathrm{cm}$ with a maximum of $85 \mathrm{~cm}$ and a minimum of $56 \mathrm{~cm}$. Tows bundles were on average shorter than scutched flax bundles, but the percentage of very short bundles i.e. below $30 \mathrm{~cm}$ was only $8 \%$. This shows that these tow bundles are longer than the size generally reported in the literature which is below $30 \mathrm{~cm}$ (Van de Weyenberg et al., 2003) or below $50 \mathrm{~cm}$ (Batra, 1985).

Purity based on shive content was assessed for the two products. Tows contained $20 \%$ of shives while scutched bundles contained less than $1 \%$ of shives. After hand removal of shives, fiber bundles were extracted as explained in section 1.2. Weight losses after extraction are reported in Table 1 . The total material loss was $3.7 \%$ and $4.4 \%$ respectively for scutched flax and flax tow. The sum of $\mathrm{B}+\mathrm{C}$ weight loss is similar for the 2 types of bundles but is slightly higher for flax tows. This can be explained by the better mechanical extraction of scutched bundles while tows were not as well separated and contained more cortical tissues.

Figure 6 shows SEM images of bundles and single fiber of the two products. Single fibers were still organized in bundles for both fiber types. The scutched bundles surface 
appears cleaner than that of the the tow bundle. There were more residues of cortical parenchyma on the tow bundles. The surfaces of scutched flax (C) and tow single fibers (D) appear to be similar.

Cross sectional area of the bundles was measured using image analysis, in order to assess the degree of fineness of the two products. Figure 2 shows a SEM image of a polished cross section of embedded bundles and the corresponding black \& white image. The total areas of analyzed objects were $2.36 \mathrm{~mm}^{2}$ and $2.58 \mathrm{~mm}^{2}$ respectively for tows and scutched fibers. Table 2 gives the descriptive statistics for measured object areas and Figure 7 shows the distribution of the cross sectional area for the two types of fibers. In this graph, the cumulative frequency is plotted versus the area. The cumulative curve shows a similar trend for the two types of fiber up to $4000 \mu \mathrm{m}^{2}$ and then a difference in the amount of larger objects. The average cross sectional area of reinforcements was $1207 \mu \mathrm{m}^{2}$ for tows and $967 \mu \mathrm{m}^{2}$ for scutched fiber. The scattering in object size is wide and maximum size is $28000 \mu \mathrm{m}^{2}$ for tows and $16000 \mu \mathrm{m}^{2}$ for scutched flax. This can be explained because some fiber bundles were grouped together by remaining cortical parenchyma and formed objects of 2 or 3 bundles. A few of these bundle groups were joined to remaining xylem particles i.e. shives. These groups were considered as individual objects by the image analysis and were of rather large size $\left(>10000 \mu \mathrm{m}^{2}\right)$ compared to individual bundles. The number of these bigger objects is low, respectively $0.5 \%$ for scutched flax and $1.5 \%$ for tow. It was possible to quantify the amount of single fibers by assuming a maximum single fiber area of $700 \mu \mathrm{m}^{2}$ (corresponding to a circle of diameter $30 \mu \mathrm{m})$. Objects ranging between $20 \mu \mathrm{m}^{2}$ and $700 \mu \mathrm{m}^{2}$ were considered as single fibers. Based on this definition $73 \%$ of the measured objects were single fibers for the two types of products. To measure the size of the fiber bundles and the mean number of fibers per bundles, the cortical residues and shives were erased from the picture, and images were 
analyzed following the procedure described. The average number of single fibers per bundle was 9 for scutched bundles and 8 for tow bundles.

To summarize, the cross sectional area of the scutched reinforcement is smaller than that of the tows, because of the shives content of tows which is around $20 \% \mathrm{wt}$., but the cross sectional area of the fiber bundles is similar for the two types of fibers and the amount of single fibers is also similar.

In this study, flax tow bundles are $10 \mathrm{~cm}$ shorter than scutched flax bundles, contain $20 \%$ of shives and slightly more cortical tissues than scutched flax. Tow bundles were coarser, because of the presence of larger bundles grouped by cortical tissues and shives $(1.5 \%$ vol. of the reinforcements). But, if these bigger objects are neglected, the fineness of the two products was quite similar. Apart from the entanglements and shives content of tows, scutched flax and flax tows have a similar morphology.

\subsection{Tensile properties of the fibers}

The validity of the sampling method was first assessed. The average diameter of all single fibers and the average diameter of the tensile tested fibers is reported for comparison in Table 3. The cross sectional diameter is likely to be more precise as the cross sections of more than 250 fibers were measured, while tensile test diameters were measured on a smaller number of fibers along their length. In addition, fibers are hand extracted for tensile tests which may introduce an experimental bias. Despite this uncertainty, tensile test diameter was close to cross sectional diameter and selected fibers were therefore considered to be representative of the batch. Average diameters were not found to be significantly different between the two products either for cross sectional or tensile diameter $(\mathrm{p}>0.05)$.

The tensile properties of single flax fibers were measured for tows and scutched fibers. The values of Young's modulus $(E)$, strength at break $(\sigma)$ and strain at break $(\varepsilon)$ are reported in 
Table 2. The mean Young's modulus of tow fibers $(51 \pm 16 \mathrm{GPa})$ was slightly higher than for scutched fibers $(47 \pm 16)$, while tensile strength of scutched fibers $(937 \pm 400)$ was slightly higher than that of tow fibers $(870 \pm 342)$. Strain at break of scutched fibers $(2.0 \pm 0.6)$ was higher than the strain at break of tow fibers $(1.8 \pm 0.5)$, which is consistent with the strength difference.

Our results show similar values for the two types of fibers considering the scatter of data. Statistical student t-tests were carried out and showed that values of Young's modulus, strength at break and strain at break were not significantly different $(\mathrm{p}>0.05)$.

The tensile properties of single fibers studied in this work are in the range of previously reported tensile properties for flax fibers under the same test conditions (Baley and Bourmaud, 2014; Lefeuvre et al., 2013; Martin et al., 2013). Andersons et al. (2009) reported single fiber tensile properties of flax for tows and scutched flax. They found a larger difference in strength at break, with values of $660 \pm 330$ and $860 \pm 330$ respectively for tows and scutched fibers. Those tests were performed on $5 \mathrm{~mm}$ gauge length samples.

Our results show that single flax fibers originating from tows bundles and scutched flax bundles have similar tensile properties despite differences due to the decortication process.

Moreover this shows that tows are not weak fiber bundles that were torn from the rest of the plant during scutching. This could also indicate that scutched bundles and tows come from the same part of the plant. Tows would be randomly removed from the material flow of the scutching line.

Based on these results both scutched fibers and tow fibers can be considered as high performance materials in terms of single fiber tensile properties even if the latter is entangled and contains shives. Applying a process of cleaning and carding to align the tows could provide a valuable product for high performance composite applications. 


\subsection{Composite tensile properties}

A series of unidirectional composites materials tensile specimens was manufactured with a wide range of fiber volume fraction ( 0.2 to 0.7$)$ for both scutched and tow fiber bundles. 21 and 24 tensile specimens were manufactured respectively with scutched and tow bundles. Figure 4 shows a cross section transverse to fibers of a unidirectional composite. Figure 8 a) shows the tensile stress/strain behavior of the composite materials. They exhibit the typical nonlinear stress/strain behavior of flax fiber reinforced unidirectional composites similar to the tensile stress/strain behavior of flax fiber (Figure 8 a)) (Baley et al., 2012; Coroller et al., 2013). The same stress/strain behavior was observed for scutched flax and tow composite samples.

Figure 8 b), c) and d) shows the individual measured values of tensile modulus, strength at break and strain at break as a function of fiber volume fraction for the flax/epoxy UD composites made of scutched flax and tow bundles. Table 4 gives the average tensile properties for four average fiber volume fractions. Tensile modulus and strength at break increase and the strain at break decreases with the volume fraction of fiber.

The tensile properties exhibit similar trends for both types of product. This means that tows or scutched bundles can give UD composites of equal longitudinal stiffness and strength. This result is consistent with the equivalent tensile properties of the single fibers shown in section 3.2. However, the maximum volume fraction achieved was lower for composite reinforced with flax tow, this could be due to the presence of coarser bundles as highlighted in section 3.1 .

Knowing the elastic modulus of the epoxy matrix and of the two reinforcements, the experimental elastic modulus of the composites can be compared to values calculated by the rule of mixtures estimation given by Equation 3. For these calculations, the value of the 
tensile modulus of the matrix and the single fibers was obtained by calculating the slope of the tensile curve between $\varepsilon=0.01$ and $\varepsilon=0.011$. As tensile properties of the single fibers were similar for the two types, the average value of strength (926 MPa) and elastic modulus (47.8 $\mathrm{GPa}$ ) were used for calculations.

$E_{\text {rom }}=E_{f} \times V_{f}+\left(1-V_{f}\right) \times E_{m}$

Where $E_{\text {rom }}$ is the calculated longitudinal modulus of the composite material, $E_{f}$ is the longitudinal modulus of the single fibers, $E_{m}$ is the elastic modulus of the matrix, $V_{f}$ is the fiber volume fraction. Upper and lower limit values are also plotted, these were calculated with the rule of mixtures by using respectively an upper value of single fiber tensile modulus defined by the mean value + one standard deviation and a lower limit defined by the mean value - one standard deviation. Values estimated by the rule of mixtures were found to fit rather well our experimental data.

The strength at break behavior is more complex, and measured values were lower than values calculated by the simple rule of mixtures. The experimental strength at break of the materials was also compared to a modified rule of mixtures given by Equation 4 (Coroller et al., 2013).

$$
\sigma_{U D}=k \times V_{f} \times \sigma_{f}+\left(1-V_{f}\right) \times \sigma_{f} \times \frac{E_{m}}{E_{f}}
$$

Where $\sigma_{U D}$ is the calculated strength of the composite materials, $\sigma_{f}$ is the strength of the single fibers. This modified model introduces an efficiency factor $(\mathrm{k})$ that takes into account the efficiency of the flax reinforcements. Indeed, the tensile strength of a composite reinforced by discontinuous unidirectional reinforcement is complex. Single flax fiber length is in the range between 30 and $80 \mathrm{~mm}$ and fibers are grouped into bundles here, whereas the simple model 
uses the strength at break of unitary fibers. In addition, the strength at break of flax fibers is scattered and the size of their polygonal shaped cross section vary along the length. Moreover, the degree of individualization of the fiber bundles plays a key role in composite failure strength. The tensile behavior at failure of the composites is not directly proportional to the strength of the fibers, since cumulative damage needs to be taken into account (Baley et al., 2012).

A $k$ value of 0.65 was found to fit the experimental data rather well for both scutched flax and tows. This value was close to the $\mathrm{k}$ value found by Coroller et al. (2013). As for tensile modulus, upper limit and lower limit values are also plotted calculated with the modified rule of mixtures by using respectively upper and lower values of single fiber tensile strength.

In summary, measured composite tensile property values are similar for both scutched flax and tow flax composites.

\section{Conclusion}

During the industrial production of flax, the decortication process yields one main product, scutched flax, and a fibrous by-product, flax tows. In this study the morphology, the tensile properties of single flax fibers and the tensile properties of epoxy/flax UD composites have been investigated for the two products.

The visual appearance of scutched flax and raw flax tows differs, owing to the entanglement and shives content, but once they have been aligned and the shives removed, flax tows are similar to scutched flax. The length of the raw tow bundles and raw scutched bundles was about $65 \mathrm{~cm}$ and $75 \mathrm{~cm}$ respectively. Morphological studies at a microscopic scale highlighted finer fiber bundles in the scutched flax. Tensile properties of single fibers originating from scutched flax and flax tows were not significantly different. The tensile characterization of epoxy/flax UD composites showed that the tensile properties of scutched flax and tows are in 
the same range for fiber volume fractions ranging from 0.2 to 0.7 . Measured values of tensile modulus follow the simple rule of mixtures for the two products while strengths follow a modified rule of mixtures with a correction for the efficiency of the flax reinforcement.

It was shown here that flax tow bundles are not short, as previously reported. Moreover, both types of product are made of high performance single fibers and the composite tensile properties were not lowered when reinforced with flax tow bundles.

These results indicate that there is potential to transform flax tows from a by-product to a reinforcement for high performance composite materials, after applying a suitable cleaning and aligning process. The use of tows would allow the development of high performance reinforcements at lower cost.

\section{References}

Akin, D.E., Dodd, R.B., Foulk, J.A., 2005. Pilot plant for processing flax fiber. Ind. Crops Prod. 21, 369-378.

Akin, D.E., Gamble, G.R., Morrison III, W.H., Rigsby, L.L., Dodd, R.B., 1996. Chemical and Structural Analysis of Fibre and Core Tissues from Flax. J. Sci. Food Agric. 72, 155165.

Andersons, J., Spārniņš, E., Poriķe, E., 2009. Strength and Damage of Elementary Flax Fibers Extracted from Tow and Long Line Flax. J. Compos. Mater. 43, 2653-2664.

Baley, C., 2002. Analysis of the flax fibres tensile behaviour and analysis of the tensile stiffness increase. Compos. Part Appl. Sci. Manuf. 33, 939-948.

Baley, C., Bourmaud, A., 2014. Average tensile properties of French elementary flax fibers. Mater. Lett.

Baley, C., Le Duigou, A., Bourmaud, A., Davies, P., 2012. Influence of drying on the mechanical behaviour of flax fibres and their unidirectional composites. Compos. Part Appl. Sci. Manuf. 43, 1226-1233.

Batra, S.K., 1985. Other long vegetable fibres: abaca, banana, sisal, henequen, flax, ramie, hemp, sunn, and coir. 4, 727-807.

Bourmaud, A., Baley, C., 2009. Rigidity analysis of polypropylene/vegetal fibre composites after recycling. Polym. Degrad. Stab. 94, 297-305.

Brown, A.E., Sharma, H. s. s., 1984. Production of polysaccharide-degrading enzymes by saprophytic fungi from glyphosate-treated flax and their involvement in retting. Ann. Appl. Biol. 105, 65-74.

Charlet, K., Baley, C., Morvan, C., Jernot, J.P., Gomina, M., Bréard, J., 2007. Characteristics of Hermès flax fibres as a function of their location in the stem and properties of the derived unidirectional composites. Compos. Part Appl. Sci. Manuf. 38, 1912-1921. 
Coroller, G., Lefeuvre, A., Le Duigou, A., Bourmaud, A., Ausias, G., Gaudry, T., Baley, C., 2013. Effect of flax fibres individualisation on tensile failure of flax/epoxy unidirectional composite. Compos. Part Appl. Sci. Manuf. 51, 62-70.

Franck, R.R., 2005. Bast And Other Plant Fibres. CRC Press.

Goubet, F., Bourlard, T., Girault, R., Alexandre, C., Vandevelde, M.-C., Morvan, C., 1995. Structural features of galactans from flax fibres. Carbohydr. Polym. 27, 221-227.

Henriksson, G., Akin, D.E., Hanlin, R.T., Rodriguez, C., Archibald, D.D., Rigsby, L.L., Eriksson, K.L., 1997. Identification and retting efficiencies of fungi isolated from dew-retted flax in the United States and europe. Appl. Environ. Microbiol. 63, 39503956.

Jauneau, A., Morvan, C., Lefebvre, F., Demarty, M., Ripoll, C., Thellier, M., 1992. Differential extractability of calcium and pectic substances in different wall regions of epicotyl cells in young flax plants. J. Histochem. Cytochem. 40, 1183-1189.

Joshi, S.., Drzal, L.., Mohanty, A.., Arora, S., 2004. Are natural fiber composites environmentally superior to glass fiber reinforced composites? Compos. Part Appl. Sci. Manuf. 35, 371-376.

Le Duigou, A., Davies, P., Baley, C., 2011. Environmental Impact Analysis of the Production of Flax Fibres to be Used as Composite Material Reinforcement. J. Biobased Mater. Bioenergy 5, 153-165.

Le Duigou, A., Pillin, I., Bourmaud, A., Davies, P., Baley, C., 2008. Effect of recycling on mechanical behaviour of biocompostable flax/poly(l-lactide) composites. Compos. Part Appl. Sci. Manuf. 39, 1471-1478.

Lefeuvre, A., Bourmaud, A., Lebrun, L., Morvan, C., Baley, C., 2013. A study of the yearly reproducibility of flax fiber tensile properties. Ind. Crops Prod. 50, 400-407.

Martin, N., Mouret, N., Davies, P., Baley, C., 2013. Influence of the degree of retting of flax fibers on the tensile properties of single fibers and short fiber/polypropylene composites. Ind. Crops Prod. 49, 755-767.

Meijer, W.J.M., Vertregt, N., Rutgers, B., van de Waart, M., 1995. The pectin content as a measure of the retting and rettability of flax. Ind. Crops Prod. 4, 273-284.

Morvan, C., Andème-Onzighi, C., Girault, R., Himmelsbach, D.S., Driouich, A., Akin, D.E., 2003. Building flax fibres: more than one brick in the walls. Plant Physiol. Biochem. 41, 935-944.

Pallesen, B.E., 1996. The quality of combine-harvested fibre flax for industrials purposes depends on the degree of retting. Ind. Crops Prod. 5, 65-78.

Rosemberg, J.A., De França, F.P., 1967. Importance of Galacturonic Acid in Controlling the Retting of Flax. Appl. Microbiol. 15, 484-486.

Salmon-Minotte, J., 2005. Flax, in: Franck, R.R. (Ed.), Bast And Other Plant Fibres. CRC Press.

Schneider, C.A., Rasband, W.S., Eliceiri, K.W., 2012. NIH Image to ImageJ: 25 years of image analysis. Nat. Methods 9, 671-675.

Sultana, C., 1992. Scutching of Retted-flax Straw, in: Sharma, H.S.S., Van Sumere, C.F. (Eds.), The Biology and Processing of Flax. M Publications.

Van de Weyenberg, I., Ivens, J., De Coster, A., Kino, B., Baetens, E., Verpoest, I., 2003. Influence of processing and chemical treatment of flax fibres on their composites. Compos. Sci. Technol. 63, 1241-1246. 


\section{List of table captions}

Table 1 Weight loss after chemical extraction of cleaned flax bundles. The sum of $\mathrm{B}+\mathrm{C}$ weight loss is higher for flax tows

Table 2 Result of the cross sectional morphology analysis of the bundles from scutched flax and flax tow. Data in parenthesis are the minimum and maximum values

Table 3 Tensile properties of single fibers

Table 4 Measured tensile properties of the Epoxy/Flax unidirectional composite materials made of scutched flax and flax tows. and comparison with Epoxy/Glass unidirectional composites made with the same molding procedure.

\begin{tabular}{ccccc}
\hline Batch & $\mathrm{A}: \mathrm{H}_{2} \mathrm{O}$ & $\mathrm{B}: \mathrm{H}_{2} \mathrm{O} 100^{\circ} \mathrm{C}$ & $\mathrm{C}:$ EDTA $100^{\circ} \mathrm{C}$ & $\mathrm{B}+\mathrm{C}$ \\
\hline Scutched flax & $9.5 \pm 2.8$ & $2.6 \pm 0.4$ & $1.1 \pm 0.1$ & $3.7 \pm 0.3$ \\
Flax tow & $10.1 \pm 0.8$ & $3.1 \pm 0.2$ & $1.3 \pm 0.2$ & $4.4 \pm 0.2$
\end{tabular}

Table 1 Weight loss after chemical extraction of cleaned flax bundles. The sum of $\mathrm{B}+\mathrm{C}$ weight loss is higher for flax tows.

\begin{tabular}{cccc}
\hline Sample & $\begin{array}{c}\text { Number of } \\
\text { Objects }\end{array}$ & $\begin{array}{c}\text { Object average area } \\
\left(\mu \mathrm{m}^{2}\right)\end{array}$ & $\begin{array}{c}\text { Average number of fibers per } \\
\text { bundle }\end{array}$ \\
\hline $\begin{array}{c}\text { Scutched } \\
\text { flax }\end{array}$ & 2641 & $967(20-15889)$ & $9(1-49)$ \\
Flax tow & 2439 & $1207(20-27793)$ & $8(1-50)$ \\
\hline
\end{tabular}

Table 2 Result of the cross sectional morphology analysis of the bundles from scutched flax and flax tow. Data in parenthesis are the minimum and maximum values. 


\begin{tabular}{cccccc}
\hline Material & $\phi_{\text {cross }}(\mu \mathrm{m})$ & $\phi_{\text {tensile }}(\mu \mathrm{m})$ & $\mathrm{E}(\mathrm{GPa})$ & $\sigma(\mathrm{MPa})$ & $\varepsilon(\%)$ \\
\hline Scutched flax & $14.1 \pm 3.4$ & $13.2 \pm 3.0$ & $47.0 \pm 15.7$ & $937 \pm 400$ & $2.0 \pm 0.6$ \\
Flax tows & $14.0 \pm 3.5$ & $12.4 \pm 2.7$ & $50.8 \pm 15.7$ & $870 \pm 342$ & $1.8 \pm 0.5$ \\
\hline
\end{tabular}

Table 3 Tensile properties of single fibers

\begin{tabular}{ccccc}
\hline Material & $\mathrm{V}_{\mathrm{f}}(\%)$ & $\begin{array}{c}\text { Young's modulus } \\
(\mathrm{GPa})\end{array}$ & $\begin{array}{c}\text { Stress at break } \\
(\mathrm{MPa})\end{array}$ & $\begin{array}{c}\text { Strain at } \\
\text { break }(\%)\end{array}$ \\
\hline Epoxy resin & 0 & $2.7 \pm 0.1$ & $78 \pm 2$ & $4.9 \pm 0.6$ \\
\hline Epoxy/Scutched flax & $26 \pm 0.4$ & $16.0 \pm 1.0$ & $234 \pm 12$ & $1.7 \pm 0.1$ \\
& $40 \pm 1.5$ & $21.0 \pm 1.5$ & $269 \pm 27$ & $1.4 \pm 0.3$ \\
& $48 \pm 4.3$ & $25.4 \pm 1.1$ & $316 \pm 41$ & $1.3 \pm 0.2$ \\
& $65 \pm 3.3$ & $33.6 \pm 4.1$ & $353 \pm 12$ & $1.2 \pm 0.1$ \\
\hline Epoxy/Flax tows & $27 \pm 3.0$ & $14.6 \pm 2.7$ & $203 \pm 25$ & $1.4 \pm 0.1$ \\
& $36 \pm 1.5$ & $17.8 \pm 1.5$ & $231 \pm 23$ & $1.3 \pm 0.1$ \\
& $42 \pm 0.9$ & $21.6 \pm 3.1$ & $280 \pm 36$ & $1.3 \pm 0.2$ \\
& $62 \pm 2.7$ & $28.6 \pm 2.2$ & $331 \pm 24$ & $1.2 \pm 0.1$ \\
\hline Epoxy/glass & $25 \pm 1$ & $21 \pm 1.1$ & $350 \pm 17$ & $2.2 \pm 0.1$ \\
(Coroller et al.. 2013) & $32 \pm 1$ & $25 \pm 0.9$ & $446 \pm 12$ & $2.3 \pm 0.1$ \\
& $45 \pm 1$ & $34 \pm 1.8$ & $547 \pm 23$ & $2.3 \pm 0.3$ \\
\hline
\end{tabular}

Table 4 Measured tensile properties of the Epoxy/Flax unidirectional composite materials made of scutched flax and flax tows. Comparison with Epoxy/Glass unidirectional composites made with the same molding procedure. 


\section{List of figures captions}

Figure 1 Diagram of the scutching line used for the flax decortication in this study. 1. Fluted roller, 2. Shives, 3.Beating turbine, 4. Blade, 5. Shives+ tows, 6. Scutched flax.

Figure 2 Image analysis of the cross section of bundles. A) Raw SEM image B) Black \& White threshold image.

Figure 3 Molding of the composite tensile specimens.

Figure 4 Cross section transverse to fibers of a composite unidirectional tensile specimen reinforced with scutched flax. $V_{f}=65 \%$. A series of 50 SEM images were stitched together to reconstruct the whole cross section of the tensile specimen.

Figure 5 Photograph of scutched flax (A), raw tows (B) and untangled and aligned tows (C).

Figure 6 SEM photographs of scutched flax fiber bundles (A), tow fiber bundles (B), scutched flax single fiber (C) and tow single fiber (D).

Figure 7 Cumulative frequency of reinforcement cross section area for scutched flax and tows in the range $20-20000 \mu \mathrm{m}^{2}$. For ease of reading the scale of the y axis is nonlinear.

Figure 8 Tensile properties of flax/epoxy UD composites reinforced with scutched flax $(\Delta)$ and tows $(\square)$ for 0.2 to 0.7 fiber volume fraction $\left(V_{f}\right)$. a) Tensile behavior of the composite materials and single fibers. The dashed lines indicate the strain range for tensile modulus calculation. b) Individual values of Young's modulus. c) Individual values of stress at break. d) Individual values of strain at break. 


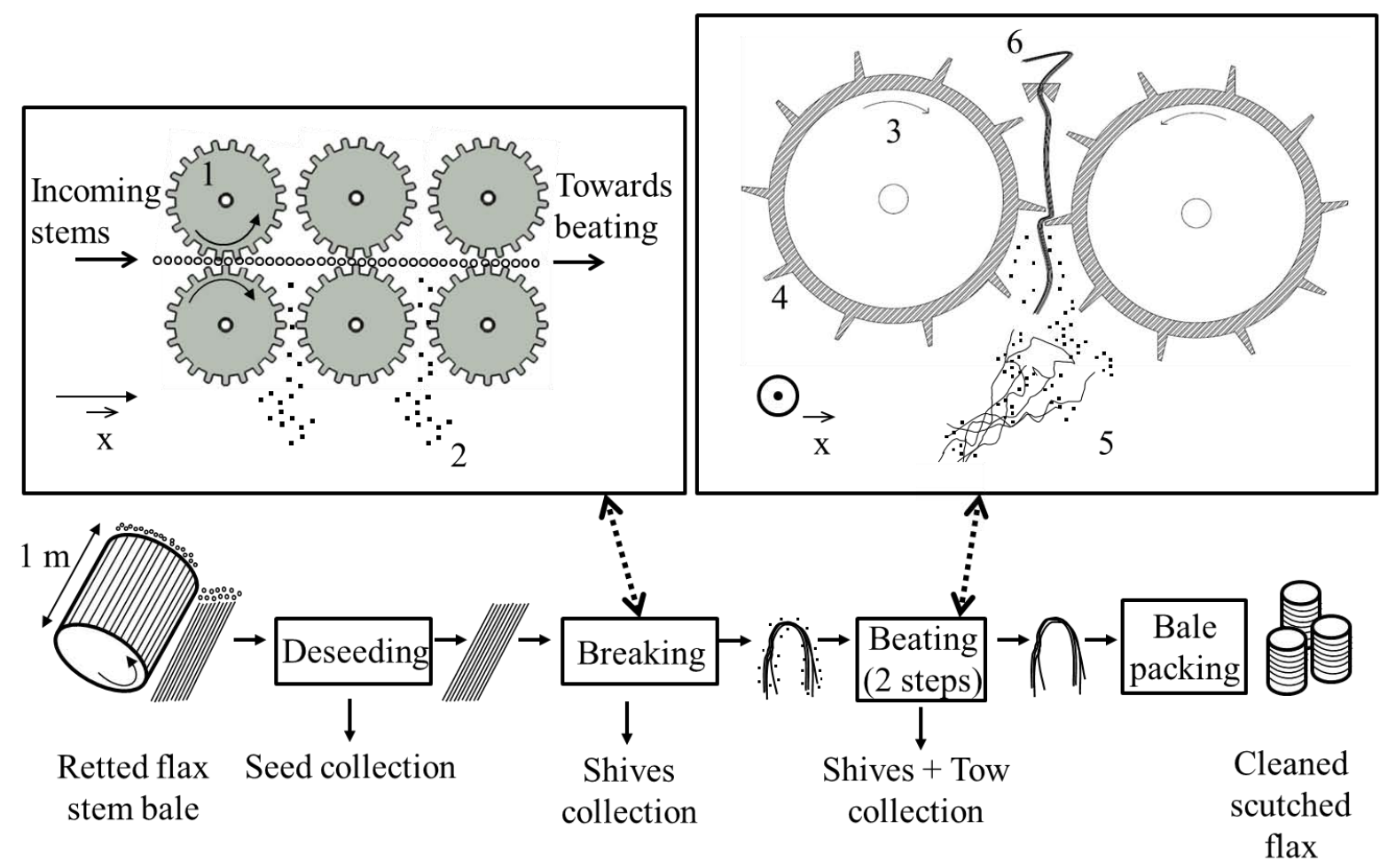

Figure 1 Diagram of the scutching line used for the flax decortication in this study. 1. Fluted roller, 2. Shives, 3.Beating turbine, 4. Blade, 5. Shives+ tows, 6. Scutched flax.
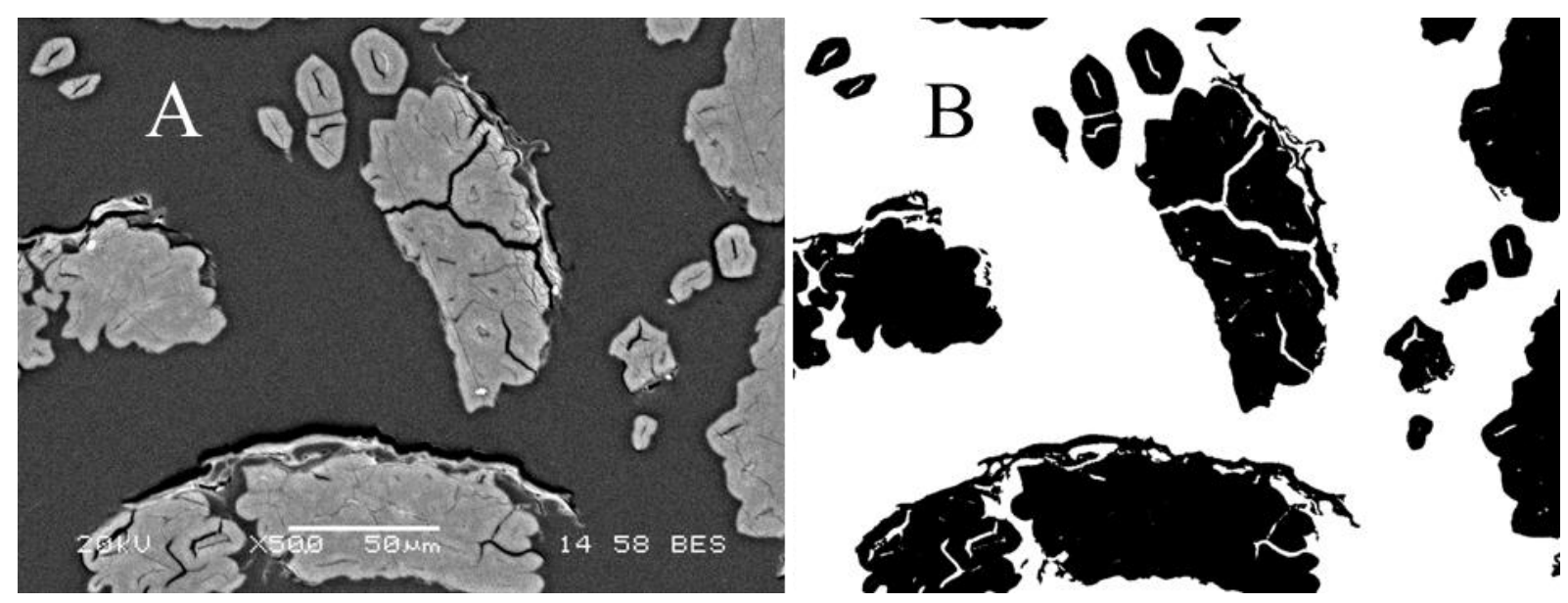

Figure 2 Image analysis of the cross section of bundles. A) Raw SEM image B) Black \& White threshold image. 


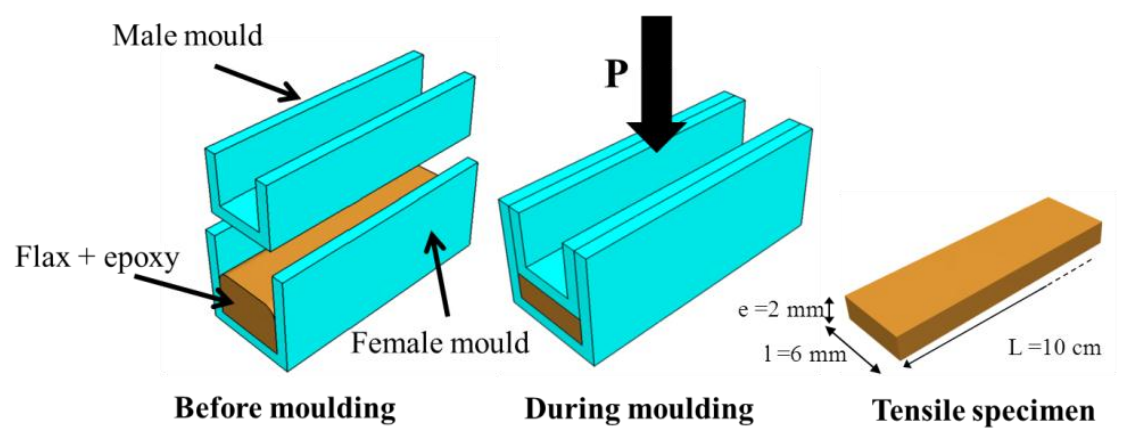

Figure 3 Molding of the composite tensile specimens.

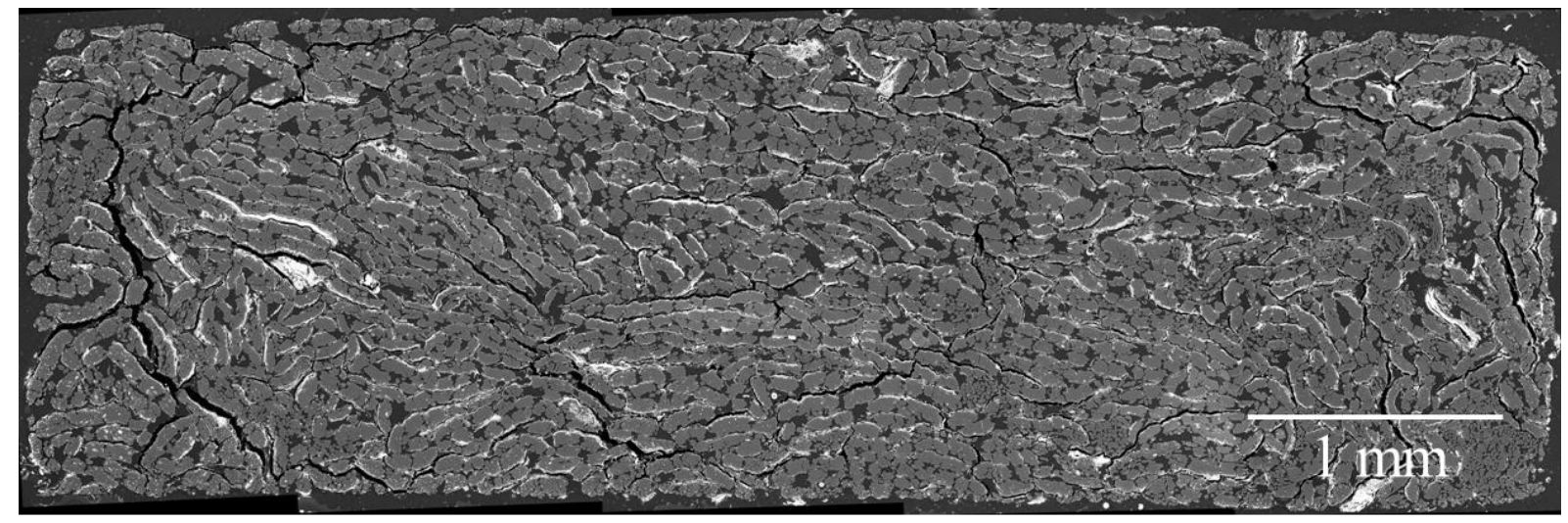

Figure 4 Cross section transverse to fibers of a composite unidirectional tensile specimen reinforced with scutched flax. $V_{f}=65 \%$. A series of 50 SEM images were stitched together to reconstruct the whole cross section of the tensile specimen. 


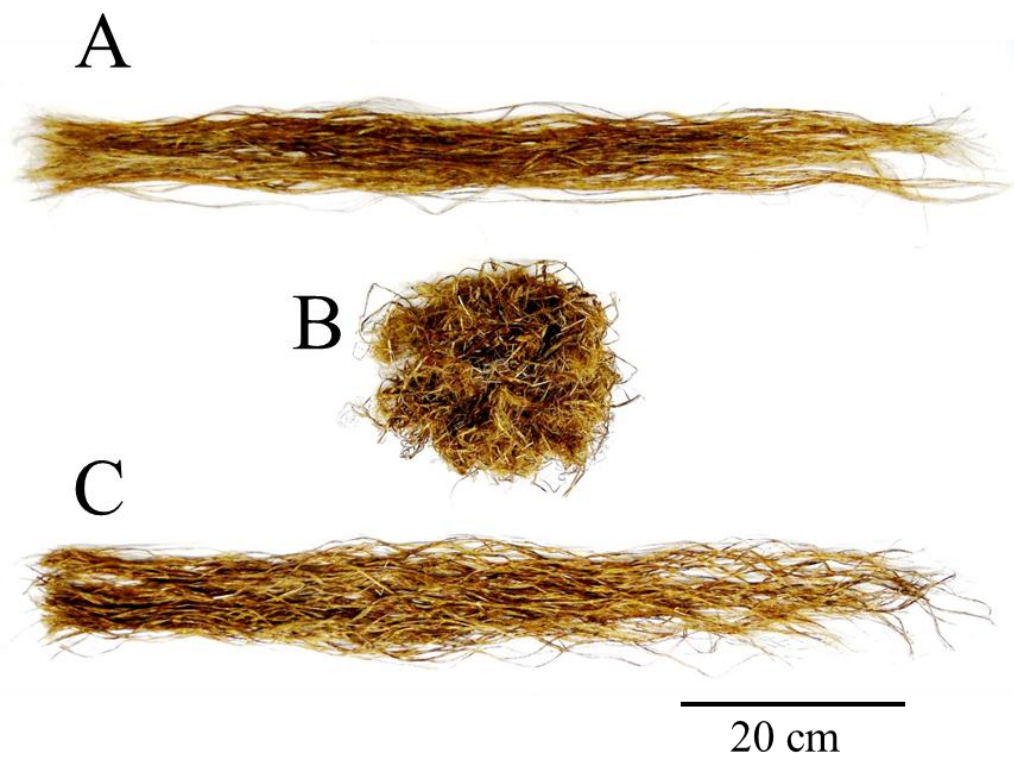

Figure 5 Photograph of scutched flax (A), raw tows (B) and untangled and aligned tows (C).

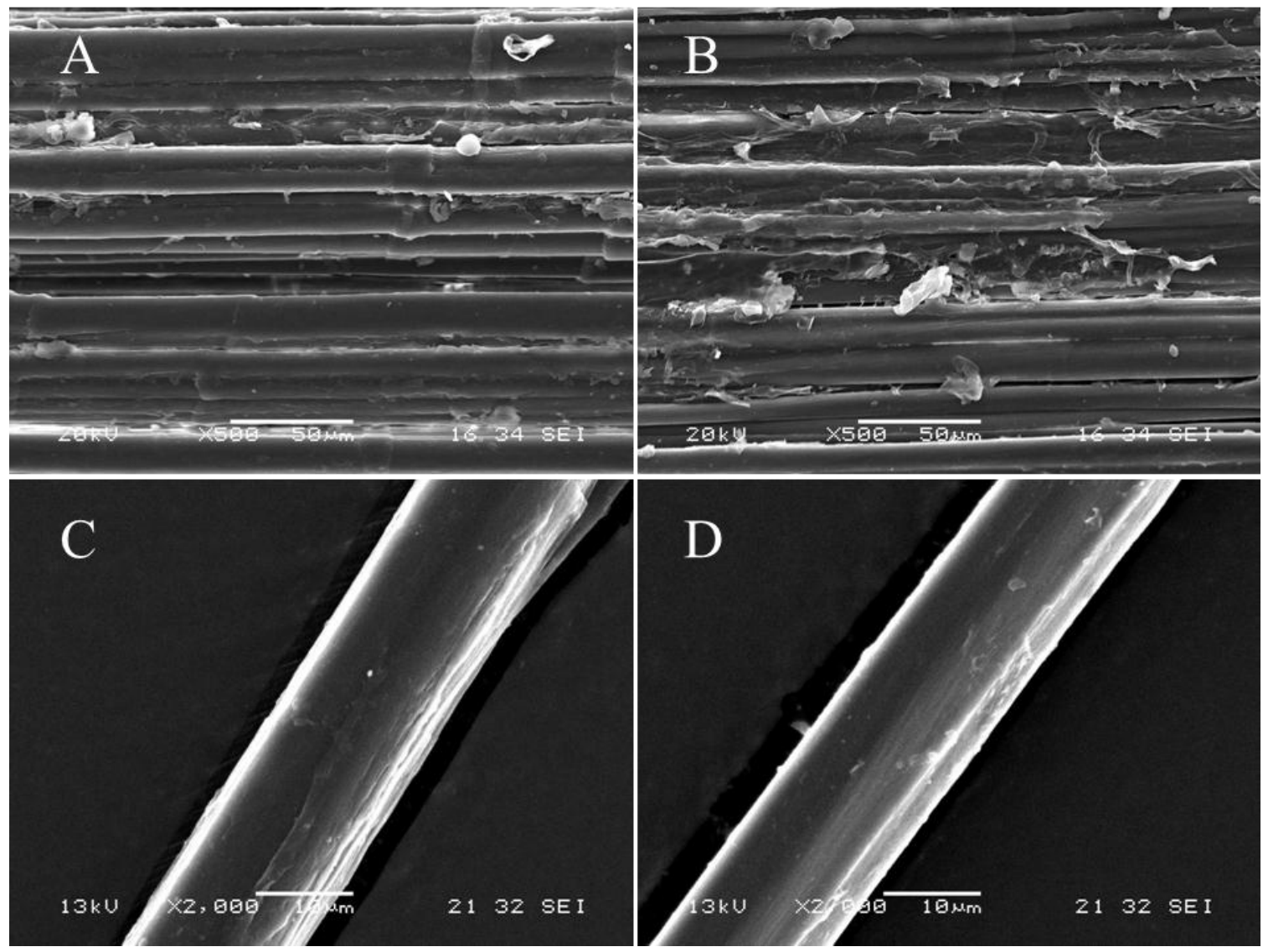

Figure 6 SEM photographs of scutched flax fiber bundles (A), tow fiber bundles (B), scutched flax single fiber (C) and tow single fiber (D). 


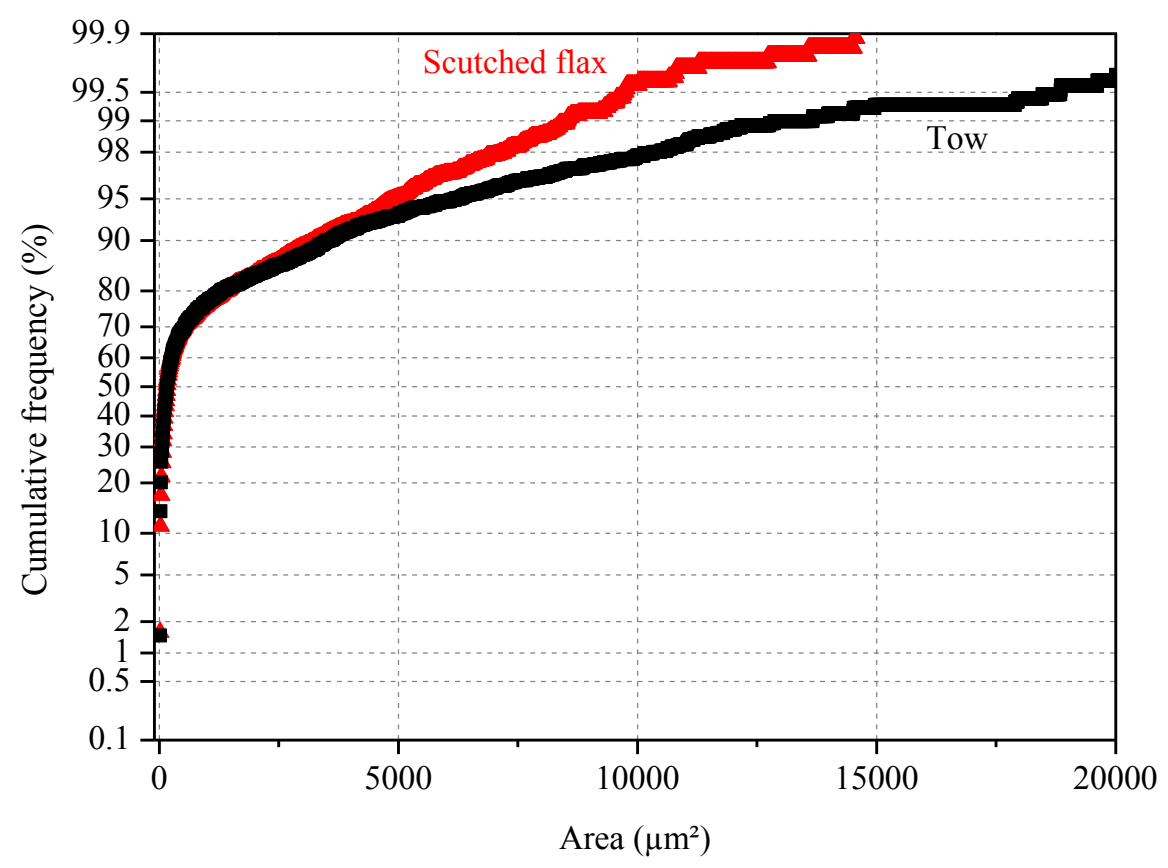

Figure 7 Cumulative frequency of reinforcement cross section area for scutched flax and tows in the range $20-20000 \mu \mathrm{m}^{2}$. For ease of reading the scale of the $y$ axis is nonlinear. 

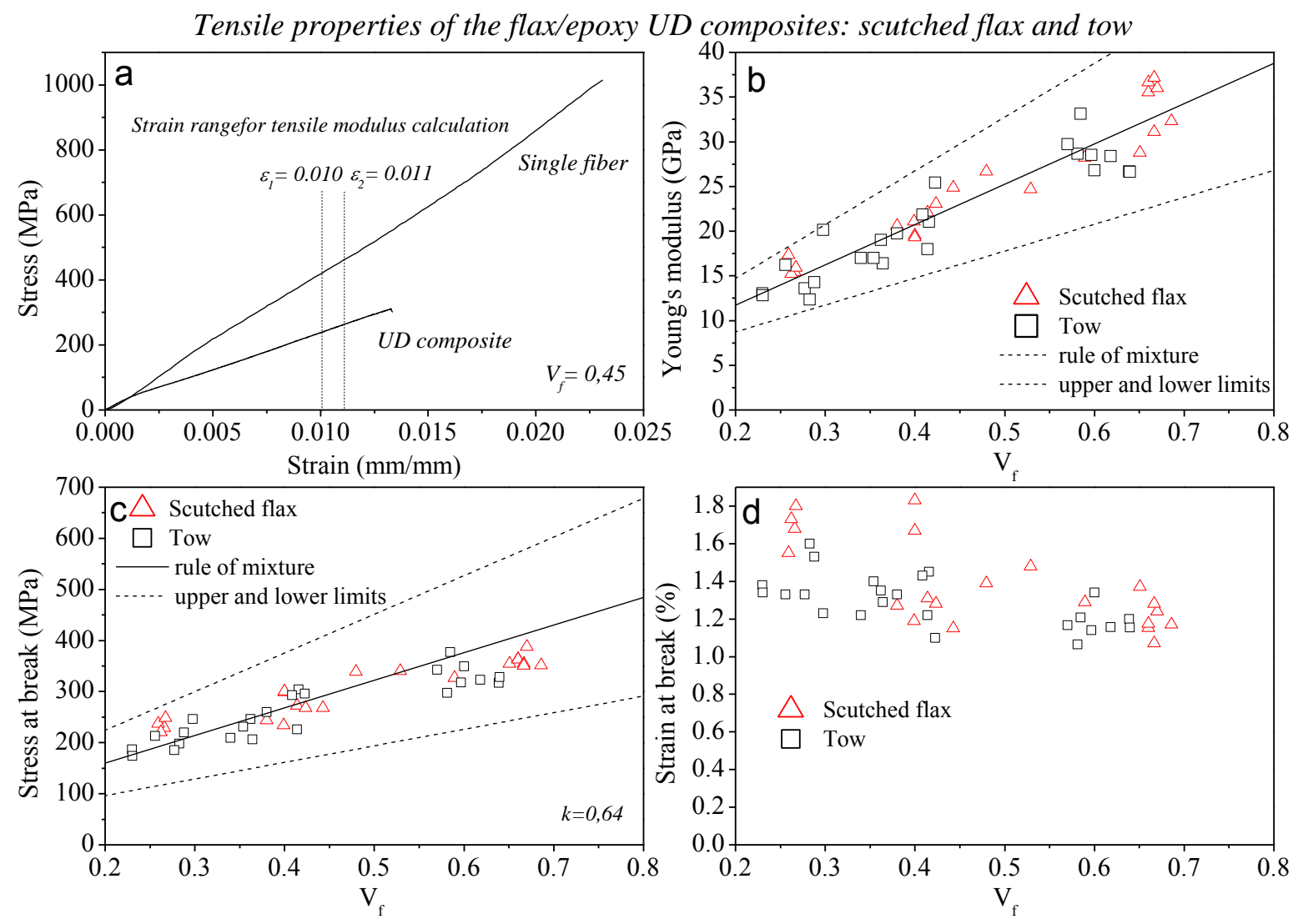

Figure 8 Tensile properties of flax/epoxy UD composites reinforced with scutched flax $(\Delta)$ and tows $(\square)$ for 0.2 to 0.7 fiber volume fraction $\left(V_{f}\right)$. a) Tensile behavior of the composite materials and single fibers. The dashed lines indicate the strain range for tensile modulus calculation. b) Individual values of Young's modulus. c) Individual values of stress at break. d) Individual values of strain at break. 